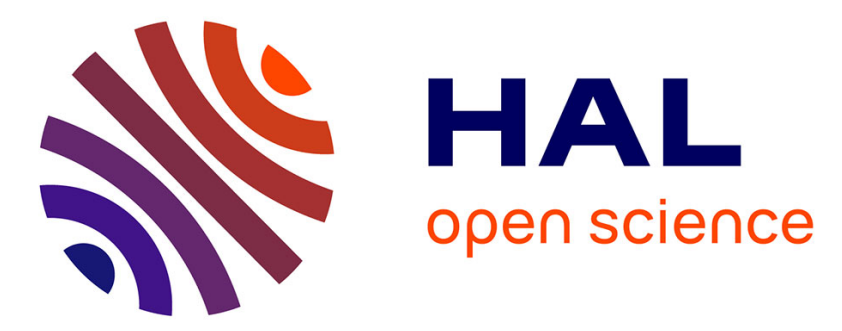

\title{
Strengthening national pharmaceutical regulation through local production
}

\author{
Jessica Pourraz, Claudie Haxaire, Daniel Arhinful
}

\section{To cite this version:}

Jessica Pourraz, Claudie Haxaire, Daniel Arhinful. Strengthening national pharmaceutical regulation through local production. Pharmaceutical Markets: An Analysis of Medicines, Regulations and Health Systems in the Global South, Routledge, In press. hal-03215338

\section{HAL Id: hal-03215338 \\ https://hal.science/hal-03215338}

Submitted on 21 Nov 2021

HAL is a multi-disciplinary open access archive for the deposit and dissemination of scientific research documents, whether they are published or not. The documents may come from teaching and research institutions in France or abroad, or from public or private research centers.
L'archive ouverte pluridisciplinaire HAL, est destinée au dépôt et à la diffusion de documents scientifiques de niveau recherche, publiés ou non, émanant des établissements d'enseignement et de recherche français ou étrangers, des laboratoires publics ou privés. 


\section{CHAPTER 1: STRENGTHENING NATIONAL PHARMACEUTICAL REGULATION THROUGH LOCAL PRODUCTION}

\section{JESSICA POURRAZ, CLAUDIE HAXAIRE, DANIEL ARHINFUL}

\section{INTRODUCTION}

This chapter provides a history of pharmaceutical regulation from independence to the present in Ghana, Côte d'Ivoire, and Benin - three countries that are geographically close but have unique itineraries and contrasting pharmaceutical profiles, whether from an institutional perspective or in terms of their industrial or commercial structures. In order to underscore the comparison, we have added Côte d'Ivoire to the two countries specifically studied in this book. Its economic resources are close to Ghana, but at the time of independence, Côte d'Ivoire opted to enact different development policies than its anglophone neighbor (Eberhardt and Teal, 2010).

As highlighted briefly in the introduction, the legal framework and pharmaceutical distribution, supply, and production systems vary from country to country, depending on their colonial legacies and post-independence policies for industrial, economic, and health development. The three countries' pharmaceutical regulations also differ considerably. They fall under the national drug policy covering the spectrum of the various ways the State is involved in pharmaceuticals, such as defining the rules and overseeing their implementation. It is therefore incumbent on the States to establish a drug regulatory system through the intermediary of a national authority. The structure, operations, and legal status of this body varies depending on the countries' administrative organization and economic resources (OMS, 2006). Thus, while Benin has had a technical directorate since the 1960s, Ghana, where the pharmacy industry's infrastructure is much denser, established a semi-autonomous agency with more resources in 2012. Falling between Benin and Ghana in terms of industrial pharmaceutical development, Côte d'Ivoire initiated its process to create an agency in 2015 that culminated in 2019. An analysis of these three case studies reveals how the evolution of pharmaceutical regulatory systems is linked to which pharmaceutical policies were chosen for procurement and support of local drug production. We will examine the various models of pharmaceutical regulation in place in West Africa and how they were constructed over time. This will shed light on how local drug production played a role in constructing regulatory systems.

Using a socio-historic approach, we have structured our narrative chronologically around the major global events confronting the States in equal measure. These include the debt crisis that 
caused the oil price shocks of the 1970s, the enforcement of structural adjustment policies in the 1980s, and the devaluation of the CFA franc in 1994 in francophone countries. From the 2000s onwards, these regulatory systems evolved in response to how diverging industrial dynamics interacted with their regulatory methods. Focusing on the role of States, non-State private actors - including private pharmacists, pharmaceutical firms, and wholesalers-as well as transnational actors ${ }^{1}$ provides a deeper analysis of how regulatory systems were created. This perspective also reflects the broader reform movements at play in the region, characterized by the process to harmonize pharmaceutical regulations at the community level and the trend to create agencies, as did Ghana and, very recently, Côte d'Ivoire. More broadly, this chapter encourages an examination of how States construct pharmaceutical sovereignty as they take ownership of their drug policies. This issue allows for an analysis of public action, including pharmaceutical and industrial policies, and the role of national and transnational actors and how they interconnect at various levels. ${ }^{2}$ By doing so, we will investigate how local production, combined with States' considerable capacity to regulate drugs, is a powerful tool in constructing pharmaceutical sovereignty.

\section{CONTRASTING DEVELOPMENT POLICIES (1960-1973)}

At the time of their independence, Côte d'Ivoire and Benin were following the French Public Health Code dictating that pharmacists maintain a monopoly and, in return, perform their job duties in person and on site. ${ }^{3}$ Meanwhile, until 1960, Ghana applied British laws under the authority of the Pharmacy and Poison Board, ${ }^{4}$ which did not require a monopoly nor any conditions for pharmacy staff, but allowed the jobs of manufacturer, wholesaler, retailer, and drug representative to be combined. Moreover, Ghanaian pharmacists were also not required to hold the majority of pharmaceutical companies' capital as was the case for manufacturers in Côte d'Ivoire from 1986 to 2015. In the francophone countries, the monopoly and its associated obligation to perform tasks in person reduced the sources of capital that could be mobilized to create industrial or commercial pharmaceutical enterprises, since they needed consolidated capital from pharmacists. In anglophone countries, combining jobs promoted

\footnotetext{
${ }^{1}$ These include multilateral United Nations agencies, like WHO and the United Nations Industrial Development Organization (UNIDO), and the United States (USAID), French (Expertise France), German (GIZ), and British (DFID) bilateral aid agencies.

${ }^{2}$ Sovereignty is a legal concept governed by public law: "Sovereignty is the quality for a State not to be bound except by its own will, within the limits of the superior principle of law and according to the collective objectives that it is called upon to achieve" (Louis Le Fur, 1896, p. 443)

${ }^{3}$ Reaffirmed in Côte d'Ivoire by Act no. 65-250 of August 4, 1965. See Chapter 3 for Benin.

4 January 1960, Public Records and Archives Administration Department (PRAAD), Ministry of Industry, GH/PRADD/RG.7/1/39, Accra, Ghana.
} 
faster accumulation of concentrated capital and allowed smaller companies to start up. After independence, the three countries chose contrasting development policies, whereby Ghana prioritized industrialization but Côte d'Ivoire and Benin promoted the exploitation of agricultural resources. This resulted in the establishment of pharmaceutical manufacturing in Ghana, while the two francophone countries strengthened the drug supply circuits inherited from the colonial period.

\section{In Ghana: prioritizing industrialization and the underpinnings of pharmaceutical regulation}

At the time of its independence in 1957, Ghana-which had substantial mineral and agricultural resources_was poorly industrialized. Kwame Nkrumah, who would become President of the First Republic of Ghana in 1960, turned to the economist William Arthur Lewis who recommended a free-enterprise production model and encouraged the use of foreign investors while dissuading the State from becoming a shareholder in or owner of industries (Lewis, 1953). Kwame Nkrumah committed the country to a vast industrialization program to foster economic development by substituting locally produced goods for imports. When local production began in 1957, Ghana was importing most of its medicines from Europe and the United States. ${ }^{5}$ This demanding and specialized industrial sector required public infrastructure (water, electricity, road networks), skilled human resources, and access to capital (Simonetti, Clark, and Wamae, 2015), conditions that Ghana did not fulfill. The government created policies to overcome these technological shortcomings and to mobilize the necessary investments. Since efficient technologies were located in the former colonial empires (Swainson, 1987), Kwame Nkrumah called on investors from the United States and Europe to develop a local industrial foundation. He initiated an industrial policy in support of setting up pharmaceutical factories through administrative, financial, and fiscal facilities and market protections for locally produced medicines that penalized imports. As a result, the British firm Major \& Co. began producing medicines in Ghana in 1957, followed by Ghana Laboratories Ltd Pioneer Companies Relief Incorporation in 1958; the English companies J.L Morrison \& Sons and Kingsway Chemists; Sterling Products Ltd (United States); Dumex Limited (Denmark); Pharco Laboratory (India); and the Netherlands African Manufacturing Company-NAMCO, a joint venture between a Dutch company and a Ghanaian wholesaler (Boateng, 2009). The public company Ghana Industrial Holding Corporation (GIHOC)

\footnotetext{
5 January 1960, Public Records and Archives Administration Department (PRAAD), Ministry of Industry, GH/PRADD/RG.7/1/39, Accra, Ghana.
} 
Pharmaceuticals Ltd, formed through a partnership with Hungary, began operations in 1967. A few private local initiatives arose on the sidelines (Gaizer, 2015), such as the still active Ayrton, created in 1965 by a Ghanaian pharmacist trained in England. The law in force in Ghana did not prohibit production units from holding shares in companies performing other functions in the sector, ${ }^{6}$ making it easier to set up a company there. These companies were even more economically viable because they could combine manufacturing activities with wholesaling, as was the case for NAMCO, or with acting as an agent-importer, in the case of Major \& Co (Baxerres, 2018).

Under Kwame Nkrumah, local pharmaceutical production was better able to meet public health priorities by providing medicines as well as the need for industrial and economic development. Local production went hand-in-hand with the development of a regulatory framework focused on enacting new legislation primarily on medicines approval and regulating the practice of the pharmacy as a profession. In 1961, the first Ghanaian legislation regulating the pharmacy profession, pharmaceuticals, and narcotics was passed: the Pharmacy and Drugs Act. This act also provided for the creation of a new authority, the Pharmacy Board, responsible for regulating the pharmacy profession and issuing authorizations to practice and licenses to distribute medicines in the private sector, inspecting manufacturers and granting their authorizations, registering products, and controlling the import and distribution of narcotics. ${ }^{7}$

\section{Côte d'Ivoire and Benin: prioritizing strengthened supply chains inherited from the colonial period}

The two francophone countries focused on maintaining and strengthening the supply systems inherited from the colonial era through central procurement offices located in France that, from their point of view, guaranteed the safety and quality of imported medicines. No plans were made to build any drug production facilities. In Côte d'Ivoire, the public sector continued to be supplied by the Central Pharmacy (Pharmacie Centrale), which replaced the colonial Pharmapro in 1958, while the two private "wholesale-distributors" 8 established before independence supplied the few distributors that worked in the country at the time: ${ }^{9}$ Laborex, a subsidiary of the West Africa Trading Company (SCOA; Société Commerciale

\footnotetext{
${ }^{6}$ Information confirmed by former officials from the Pharmacy Council and the FDB of Ghana during the Globalmed symposium in Ouidah in 2018.

${ }^{7}$ Interview with a former FDB executive in Accra on April 1, 2015.

${ }^{8}$ This profession will be discussed in Chapter 3 .

${ }^{9}$ There were 42 private pharmacists in 1970.
} 
d'Afrique de l'Ouest), an importer since 1949, and the Pharmaceutical Group of Côte d'Ivoire (GOMPCI; Groupement Pharmaceutique de Côte d'Ivoire). ${ }^{10}$ During the first ten years following independence, Ivorian pharmacists, primarily trained in France, opened private pharmacies or held positions in pharmaceutical companies or Ministry of Health directorates.

At this time, Dahomey, which would become the People's Republic of Benin in 1975, was experiencing political instability that hampered investment. From independence in 1960 to Mathieu Kérékou's assumption of power in 1972, the industrial sector remained underdeveloped and the pharmaceutical industry was inexistent. As will be discussed in the next chapter, the public sector was still supplied by Pharmapro, backed since 1964 by the Benin National Office of Pharmacies (ONP; Office National des Pharmacies du Bénin) that oversees drug distribution to a few private pharmacies and health facilities.

From a legislative standpoint, the French Public Health Code required some modifications in terms of regulating the profession and the conditions for importing and registering medicines. The National Order of Pharmacists of Côte d'Ivoire was established in $1960,{ }^{11}$ and its Beninese counterpart was set up in $1973 .{ }^{12}$ In addition to protection from the Order, pharmacists in Côte d'Ivoire are also protected by trade unions, and in this liberal economy are even able to establish "mutuelles" (insurance cooperatives), buy shares in pharmaceutical companies, and then set themselves up as financial holding companies, ${ }^{13}$ whose importance will be explained below. In Benin, these groups would establish themselves much later (see Chapter 2). The 1960 decree defining the powers of the Ivorian Ministry of Public Health ${ }^{14}$ created the Directorate of Pharmaceutical Services (DSP; Direction des Services Pharmaceutiques); Benin's General Directorate of Pharmacies (DGP) was established that same year. Both issue installation licenses and inspect pharmaceutical establishments. In addition to private pharmacies, these directorates oversee the Chemistry and Fraud Laboratory and the Central Pharmacy in Côte d'Ivoire; and Pharmapro and the ONP in Benin.

In $1965,{ }^{15}$ Côte d'Ivoire reaffirmed the criteria governing drug registration, which did not occur in Benin until between 1973 and 1976 through the enactment of an initial series of

\footnotetext{
${ }^{10}$ Created by Jean Mazuet, the first French pharmacist posted in Côte d'Ivoire in 1936, and later developed in other francophone African countries (Mazuet, 1987).

${ }^{11}$ By Act no. 60-272 of September 2, 1960, followed by a code of ethics, established through Act no. 62-249 of July 31, 1962. For the industry, owner-pharmacists who are manufacturing are in one section (B) as opposed to pharmacists who are distributing (C), which clearly separates the two functions, unlike in Ghana. Pharmacists who are salaried employees in industry management fall under section $\mathrm{D}$, distinct from that of owners.

${ }^{12}$ Ordinance no. 73-38 of April 21, 1973.

${ }^{13}$ These are companies whose shareholders could have an influence on the company's decisions.

${ }^{14}$ Decree no. 61-34 of January 14, 1961, on the re-organization of the Ministry of Public Health, later changed to Decree no. 69-48 of January 20, 1969.

${ }^{15}$ Act no. 65-250 of August 4, 1965.
} 
ordinances ${ }^{16}$ that decreed that only State-approved structures are authorized to import drugs and are required to report to the DGP. ${ }^{17}$ The two countries recognized the need to control imported pharmaceuticals through a sales authorization in Côte d'Ivoire and a visa in Benin, issued by the respective pharmaceutical regulatory authority (DSP in Côte d'Ivoire and DGP in Benin) after checking the manufacturing conditions. In Côte d'Ivoire, the law of 1965 established a registration fee paid to the Treasury for pharmaceuticals, whose rate and payment conditions are fixed by decree, as is also the case in Benin. This law also provided for the creation of a registration commission (or technical commission in Benin) whose composition and function were also defined by decree. However, registration fees paid to the Treasury are not transferred to the Beninese DGP and are only partially transferred to the Ivorian DSP, thus limiting their resources. At that time, drug registration was fairly lax, essentially consisting of paying registration fees to the Public Treasury and providing a technical dossier.

\section{A TURNING POINT IN THE 1980s: THE GLOBAL DEBT CRISIS AND STRUCTURAL ADJUSTMENT PROGRAMS}

The oil crisis of the 1970s slowed industrial activity and foreign investments in the pharmaceutical sector in Ghana until the late 1980s (Mackintosh et al., 2015). The crisis also raised countries' costs of imported medicines. In Côte d'Ivoire and Benin, this affected public pharmaceutical supply structures and pushed the countries to consider producing medicines locally, a move that challenged the global trend to deindustrialize. At the international level, the essential medicines policy, initiated by WHO in 1977, encouraged the use of generics and establishing production units in the Global South.

\section{The flight of multinationals from Ghana and the advent of Indian initiatives}

Throughout the 1970s and early 1980s, the Ghanaian economy experienced a severe crisis that forced many health professionals to leave the country (Senah, 1997). Jerry John Rawlings, who assumed power through a military coup d'état in 1981, was compelled to adopt structural adjustment programs imposed by the Bretton Woods financial institutions until 1992 (Whitfield and Jones, 2007). The launch of an economic recovery program in 1983, combined with trade liberalization, brought an end to the protectionist measures implemented under Kwame Nkrumah. Opening the market to competition, however,

\footnotetext{
${ }^{16}$ For example, Ordinance no. 75-7 of January 27, 1975, on governing medicines in Dahomey.

${ }^{17}$ Ordinance no. 73-68 of September 27, 1973, defining the conditions for the importation of pharmaceuticals and wound care products in Dahomey.
} 
highlighted the lack of competitiveness of pharmaceutical companies based in Ghana. Starting in the late 1980s, the global crisis, coupled with economic reforms, led pharmaceutical multinationals to decrease, if not cease, activities with their subsidiaries (Boateng, 2009). During this period, only two Indian-owned companies were established: Letap Pharmaceuticals Limited in 1983 and M\&G Pharmaceuticals Ltd in 1989. Development of the pharmaceutical industry in India, starting in the 1970s (Chaudhuri, 2005), triggered changes in the structure and circulation of global drug markets, especially from Asia to Africa. Indian companies began to play a major role in technology transfer to the African continent.

\section{Reorganizing public procurement and the start of an industrial policy in francophone countries}

In Côte d'Ivoire, local actors developed initiatives in response to the international events. In his pursuit for long-term economic sovereignty, the first president, Felix Houphouët-Boigny, sought to develop local pharmaceutical production. ${ }^{18}$ This required training for pharmacists. Although planned for several years, the School of Pharmacy was not opened until $1977 .{ }^{19}$ The school offered international-level training reserved for Ivorian citizens, adapted to the needs of local populations. ${ }^{20}$ However, Ivorian pharmacists envisaged pharmaceutical sovereignty from a financial perspective. A type of association based on capital drawn from professionals emerged in Côte d'Ivoire that would play a major role there. These were holding companies that gave pharmacists considerable influence on the companies in which they were shareholders. Private pharmacists primarily owned shares in the two wholesale-distributors (Laborex and GOMPCI). In 1975, some of these pharmacist shareholders united in the Eurapharma holding company, so they could pressure the French central procurement office, Continental Pharmaceutique, based in Rouen, the office that Laborex depended on. ${ }^{21}$

In 1980, the consequences of the global crisis, structural adjustment programs, and the withdrawal of French development aid programs led Felix Houphouët-Boigny to enlist actors from the pharmaceutical sector to consider setting up a drug production facility in Côte d'Ivoire. With no support from wholesale-distributors or French industrials, it took six years to carry out the project. Côte d'Ivoire benefited from the problems of Rhône-Poulenc, which planned to outsource its production abroad in units acting as manufacturers and working

\footnotetext{
${ }^{18}$ Interview with the first faculty dean, André Rambaud, (November 2018) and his presentation in June 2018 during the 40year commemoration of the Research and Training Unit (UFR, Unité de Formation et de Recherche) for pharmaceutical sciences at the Houphouët-Boigny University in Cocody (Abidjan).

${ }^{19}$ By President Felix Houphouët-Boigny, Professor Michel Attiso, and pharmacist Jean Baptiste Mokey.

${ }^{20}$ By 2015, it had trained over 2000 graduates (DPML, National Pharmaceutical Policy, 2015, p 18).

${ }^{21}$ These actors are also present in Benin, which will be discussed in the next chapter.
} 
under a license (Barral, 2008). The first Ivorian law on the pharmaceutical industry was enacted in 1986, requiring Ivorian pharmacists to hold senior-level manufacturing and control positions, as well as stipulating that they be the majority shareholders of the company's capital. Ivorian private pharmacists could then join forces to mobilize the necessary capital and, like the wholesale-distributors, invest in the first production company, Cipharm, opened in May 1988, operating under the Rhône-Poulenc license. ${ }^{22}$ From the time of its creation until the International Monetary Fund (IMF) put an end to it, this firm enjoyed a reserved market. ${ }^{23}$ A second private production company, Galefomy, specializing in dermatological preparations, was established in 1989 in Bouaké, the country's second largest city. It was financed by a private pharmacist ${ }^{24}$ who had accumulated capital through his shares in the wholesaledistributors' capital fund, just as Western pharmacies of the nineteenth century once did (Ruffat, 1996). He was able to get around the rules requiring a pharmacist to run the company and forbidding pharmaceutical functions from being combined through a one-time agreement with the president of the Order of Pharmacists, who wanted to promote the establishment of production facilities.

This process resulted in strengthening the institutions that oversee regulation in Côte d'Ivoire. Following the 1983 Etats Généraux de la Santé, a citizens' forum to gather health information, the Ministry of Health was reorganized to favor the relative autonomy of its subsidiary structures. The Central Pharmacy became the Côte d'Ivoire Pharmacy of Public Health (PSPCI), established as a Public Institution of an Industrial and Commercial Nature (EPIC in French). ${ }^{25}$ In 1984, the Laboratory of Chemistry and Fraud became a central autonomous directorate of the Ministry of Health. Later, a National Pharmacovigilance Commission was created. ${ }^{26}$ The first national list of essential medicines was created in 1989.

Benin was also facing a dire economic situation, and in 1980, the ONP and Pharmapro went bankrupt, causing severe drug shortages. In response, the Beninese State, which had minimal financial resources of its own, entered a phase to privatize the pharmaceutical supply and distribution systems. The private sector, thus far repressed by the Marxist government, found a place in the pharmaceutical landscape (Baxerres, 2013). In 1982, President Mathieu Kérékou used the family-owned capital of a Beninese biologist living in France who created

\footnotetext{
${ }^{22}$ The capital was distributed as follows: Rhône-Poulenc 26\%, Roussel-Hoechst 13\%, Sanofi 13\%, Ivorian pharmacists $28 \%$, GOMPCI 10\%, and Laborex 10\%. CIPHARM manufactured the specialties of three pharmaceutical companies: Nivaquine ${ }^{\circledR}$, aspirin, and Flavoquine ${ }^{\circledR}$.

${ }^{23}$ Interview with Assane Coulibaly, head pharmacist and deputy director of Cipharm until December 2014: medicines produced by Cipharm are not imported.

${ }^{24}$ Interview with Dr. Mamadou Yacine Fofana in February 2018.

${ }^{25}$ By Decree no. 84-764 of June 6, 1984.

${ }^{26}$ By Order no. 249 MSP DSPH of November 18, 1988.
} 
the private firm Pharmaquick to produce medicines locally and reduce the cost of imports. The industrialist's arrival crystalized numerous tensions among Beninese private pharmacists, who accused him of violating the monopoly rules since he was not a pharmacist. In 1987, IMF programs imposed economic measures on Benin aimed at decreasing public expenses and thus endorsed State withdrawal from the health sector (Baxerres, 2013). Benin was subject to two structural adjustment programs, first from 1989 to 1991 and then from 1991 to 1994. The Central Purchasing Office of Essential Medicines and Medical Consumables, or CAME, was created in 1989 to replace the ONP and Pharmapro, prompted by the World Bank and other development partners (see Chapter 2).

\section{PRIVATIZATION OF THE PHARMACEUTICAL SECTOR IN THE 1990s}

Serious drug shortages continued in the 1990s in the three countries, generated in part by the phenomenon of deindustrialization described above in Ghana and by the devaluation of the CFA franc in 1994 in Benin and Côte d'Ivoire. No longer able to pay the bills for imported drugs, these two francophone countries used less expensive generic medicines. This was all the more necessary because the cost recovery policy promoted by the Bamako Initiative required that populations cover a portion of medicine prices. In Ghana, this meant the implementation of the "cash and carry" policy starting in 1992 (Arhinful, 2003). From then on, privatization of the pharmaceutical sector then underway seemed to solve the availability problems surrounding pharmaceuticals.

\section{Recovering industrial investment through local private capital and strengthening drug regulation in Ghana}

Since the mid-1990s, industrial investment has picked up in Africa, in large part due to local investors (Mackintosh et al., 2015). In Ghana, the flight of multinationals allowed private Ghanaian entrepreneurs, some who were pharmacists, to buy back production facilities created after independence and to start manufacturing drugs, thus contributing to the "indigenization" of the pharmaceutical sector. ${ }^{27}$ The capital mobilized by this new generation of Ghanaian industrialists came from their business activities in medicine importation, promotion, and distribution (see Chapter 3). The Ghanaian State continued to play a determining role in supporting local industry by promoting the creation of markets reserved for local manufacturers using a list of 14 medicines prohibited for import and reserved for

\footnotetext{
27 "Indigenization" describes the origin of capital and indicates that it comes from local private individuals. It differs from nationalization, which means that capital belongs to the State.
} 
local production ${ }^{28}$ and a $15 \%$ discount on prices for public tenders. Fiscal advantages were also granted to local producers, such as tax exemptions on imported raw materials, machines, and equipment needed to manufacture finished products ${ }^{29}$ and simplified registration. Thus, the interventionist policy implemented by the Ghanaian State offers the market conditions that local industries need in order to develop and is a form of "educational protectionism" (Guennif and Mfuka, 2003, p.85). It does not, however, solve the problem facing local companies that want access to capital and technology.

Besides the need to regulate, support, and guide increased local production, Ghana's national regulatory authority was confronted with increasingly more generic medicines coming from Asia during the 1990s that needed quality and origin inspections before registration. It became necessary to separate the regulation of products from the regulation of professional practice and to create an independent authority solely for regulating products, whether imported or produced locally. The Pharmacy Board disappeared and was replaced by the newly created Pharmacy Council and the Food and Drugs Board (FDB). In 1994, Pharmacy Act 489 created the Pharmacy Council to control the pharmacy practice and the registration of pharmacists and licensed chemical sellers. The Food and Drugs Board (FDB), created in 1997 following the enactment in 1992 of the Food and Drugs Law, managed the control of drug manufacturing, import, export, distribution, use, and advertisement. Overseen by the Ministry of Health, the FDB enjoys relative autonomy and independence in its decision-making. Comprising two divisions at its beginnings-with one dedicated to medicines, cosmetics, medical devices, and household chemical substances and the other dedicated to foods - the governing board was composed of 14 individuals, including 5 pharmacists. Operationally the FDB seeks the support of external actors to implement some activities: USAID for quality surveillance, and the United States Pharmacopeia (USP) and WHO for laboratory equipment and training. The industrial policy was combined with strengthening the regulatory authorities' capacities and competencies since the FDB was gradually acquiring a pool of pharmacist-inspectors who, on average, conducted about 20 inspections of manufacturing plants each year in Ghana. Over time, the expertise acquired during these inspections gradually gave FDB officials the necessary expertise to conduct inspections abroad. Pharmaceutical companies exporting their medicines to Ghana had to pay a fee when registering their medicines to cover the costs associated with conducting inspections at their

\footnotetext{
${ }^{28}$ This includes paracetamol, ampicillin, chloramphenicol, tetracycline, aspirin, and diazepam.

${ }^{29}$ Compared to $10 \%$ import taxes on finished products.
} 
production sites. ${ }^{30}$ Ghanaian inspectors carried out about 30 inspections abroad per year, mainly in Asia where most of the generic medicines came from (FDA, 2011-2015). They also received training within multinationals, such as Cipla in India, the US FDA, and the Medicines and Healthcare products Regulatory Agency in the United Kingdom.

\section{The indigenization of the industry and distribution in francophone countries}

In Côte d'Ivoire, the early 1990s witnessed the deployment of Ivorian pharmacists' competencies and capital throughout the pharmaceutical sector. The cooperative of private pharmacists, Copharm, promoted financial assistance within the profession, ${ }^{31}$ based on the model of cooperatives described by Sueur (2017) in France. Two new pharmaceutical companies were created, with an even more uncertain future than Cipharm. They were Dermopharm $^{32}$ in 1992 and Pharmivoire in 1991. Pharmivoire, created by two university pharmacists who got loans from Proparco, a subsidiary of the French Development Agency, which supports the private sector by granting loans. It would become Pharmivoire Nouvelle in 1999, following a recapitalization by Copharm (Aouely et al., 2017).

At the same time, the process to indigenize wholesale-distributors' capital continued when 161 Ivorian private pharmacists, ${ }^{33}$ who were shareholders of the Ivorian branch of Laborex, or Laborex-CI, repurchased the majority of the capital of this company (55\%) in 1990. They did this by exchanging their Laborex shares for shares in Pharmafinance, the holding company provided for by Ivorian law that they had just created and that they used to take control of this former Ivorian subsidiary from the SCOA group, namely Laborex-CI. Thus in 1991, Pharmafinance created Pharmaholding, which became Ubipharm, and, in 2000, acquired a purchasing platform, Planet pharma, approved by the French Agency for the Safety of Health Products. Today, Ubipharm is the leading drug distributor in francophone African countries, "a 100\% African success story" (Coulegnon, 2013). Owners of private pharmacies also sat on wholesale-distributors' boards of directors. Therefore, Ivorian pharmacists continued to seek economic sovereignty with share buyouts in order to claim majority ownership in two new wholesale-distributors: Copharmed in 1996 and DPCI in 1999. ${ }^{34}$

\footnotetext{
${ }^{30}$ In 2009, this fee was USD 700 for a local firm and USD 20,000 for a foreign firm (source: FDA).

${ }^{31}$ In 1993, the Order of Pharmacists of Côte d'Ivoire entrusted a colleague trained in management with the task of "creating a cooperative, COPHARM, to mobilize savings, provide financial assistance between pharmacists, and carry out joint projects" (interview with Elisabeth Kakou conducted by S Cessou for Afrique Méditerranée Business, April-May 2017, p 32-35).

${ }^{32}$ Dermopharm presents itself as a family business created by an Ivorian private pharmacist, who died in 2016.

${ }^{33}$ Interview with the Director General of Ubipharm, Gérard Mangoua, for Forbes Afrique (Coulegnon, 2013).

${ }^{34}$ Through the creation of a holding company with Ivorian capital in 1996, Copharmed, to control their shares in Eurapharma (repurchased by the CFAO Group in 1996). However, unlike Laborex-CI, Copharmed remains a partner of the Eurapharma group.
} 
Confronted with drug shortages caused by the devaluation of the CFA franc, the local firms Cipharm and Pharmivoire Nouvelle were able to provide some essential medicines and infusion solutions. They were joined by the Pharmaceutical Laboratory of Côte d'Ivoire (LPCI, Laboratoire Pharmaceutique de Côte d'Ivoire), created in 1997 by Ivorian university pharmacists to prepare herbal medicines; but whose activity was limited to repackaging, and by Lic Pharma, created in 2002 with Chinese capital. ${ }^{35}$ Lic Pharma has a unique financial arrangement relative to the 1986 law on pharmaceutical companies, which requires that pharmacists hold the majority of a company's capital. This resulted in a bilateral agreement between the government of the new president Henri Konan Bédié and the Chinese State in 1995, resulting in a series of projects funded by the Chinese Exim-Bank in 1996 (Caubin, 2010). Loans to the Ivorian government were lent on to private operators to fund productive projects through joint ventures, including Lic Pharma. In Benin, the devaluation of the CFA franc and the procurement crisis helped strengthen the role of the CAME, which purchases and distributes generic medicines, as well as the private company Pharmaquick, which produces them locally. The second structural adjustment program from 1991 to 1994 strengthened the country's commitment to a phase of economic liberalism (Gbetoenonmon, 2013). The procurement system was gradually expanding with the establishment of two new private wholesale-distributors (see Chapter 2).

Just as in Ghana, sourcing generics from Asia and creating new local industries in Côte d'Ivoire required strengthening Beninese and Ivorian regulations on importation and registration. As a result, the technical directorates of the Ministries of Health were restructured. In Côte d'Ivoire in 1994, President Bédié reorganized the Directorate of Pharmaceutical Services, which became the Directorate of Pharmacy, Medicine, and Laboratories (DPML, Direction de la Pharmacie et du Médicament et des Laboratoires) in 1997. In Benin, the Directorate of Pharmacies and Laboratories' prerogatives were broadened to become the Directorate of Pharmacies and Diagnostic Investigations (DPED, Direction des Pharmacies et des Explorations Diagnostiques). Between 1994 and 1995 in Benin, the WHO essential medicines program supported strengthening registration procedures for medicines for human use. ${ }^{36}$ These procedures were revised in 1997 with Decree no. 97-632 of December 31 to increase pre-regulation screening and make the registration process more transparent

\footnotetext{
${ }^{35}$ According to our sources, the capital is now entirely Chinese, coming from a construction company, and is not a branch of a Chinese pharmaceutical company. The Chinese staff is also not from the pharmaceutical industry; instead, they are chemical and agribusiness technicians supervised by Ivorian pharmacists.

${ }^{36}$ WHO Archives, E19-445-3BEN, WHO Action Programme on Essential Drugs-Benin, 1989, Jacket No. 3.
} 
and rigorous. ${ }^{37}$ This went hand in hand with creating or strengthening quality control systems. In Benin, the creation of an analytical laboratory was created in 1999. In Côte d'Ivoire, the national laboratory, created in $1991,{ }^{38}$ was upgraded to a Public Establishment of an Administrative nature (an EPA in French) and became the National Laboratory of Public Health (LNPS).

Despite these institutional reforms, the skills developed by Beninese and Ivorian technical directorates particularly for inspection remained very limited in comparison to those of the FDB in Ghana, where a dense industrial infrastructure platform encouraged the FDB to build up production site inspection capacities early on. This last factor is key to highlighting how local production processes are entangled with pharmaceutical regulation.

\section{THE 2000s: DIFFERING LOCAL INDUSTRIAL DYNAMICS}

\section{Continuing Ghana's industrial policy}

Throughout the 2000s in Ghana, continuation of the industrial policy led to the creation of drug manufacturing pharmaceutical companies by Ghanaian pharmacists - such as Kinapharma, Danadams, and Ernest Chemists—bringing the total number of companies to 36. Most started out as import wholesalers for international companies. Once seen as intermediaries, these wholesaler-retailers became manufacturers by accumulating capital (Braudel, 1985; Baxerres, 2018). They received Indian and/or Chinese technical assistance: for example, Danadams was created through a Sino-Ghanaian partnership. In the same period, new Indian Ghanaian companies ${ }^{39}$ — such as Eskay Therapeutics Ltd in 1998, Pharmanova Limited in 2005, and Unichem Industries in 2010 - opened in Ghana, taking advantage of an environment that made it easier for them to produce generic versions of drugs still under patents. $^{40}$

\section{How the Ivorian political crisis affected the industrialization process}

In Côte d'Ivoire, the military-political crisis that began in 2000 saw Laurent Gbagbo's accession to the presidency and ignited ten years of turbulence and deregulation resulting in clashes, after which Alassane Ouattara came to power.

\footnotetext{
${ }^{37}$ The decree grants the Technical Commission for Medicines, in charge of issuing the Marketing Authorization (MA), the power to consult experts in order to deepen document assessment and analysis.

${ }^{38}$ By Decree No. 91-654 of October 9, 1991.

${ }^{39}$ These three companies are owned or were set up by Indians who had Ghanaian nationality.

${ }^{40}$ Ghana is one of the countries that is not bound to the World Trade Organization (WTO) agreements on Trade-Related Aspects of Intellectual Property Rights (TRIPS).
} 
The wholesaler-distributors Ubipharm and Eurapharma managed to hold on during the crisis, as did the local pharmaceutical companies Cipharm ${ }^{41}$ and Pharmivoire Nouvelle. Despite the 1986 law in force, in 2007 the Gbagbo government authorized the establishment of the Olea company using Italian capital and belonging to non-pharmacist Milanese businessmen. The new initiatives fall under a form of capitalism that bypasses the rules on monopolies and the origin of capital. Other companies tried to start up with no lasting success, including a subsidiary of the Canadian firm Rougier. However, in those troubled times, wholesalerdistributors no longer risked investing in local production as they did when Cipharm was created.

Starting in 2011, the government of Alassane Ouattara set out to promote the development of local pharmaceutical companies to ensure better access to medicines, seeing more investment opportunities in a booming market (Coulibaly, 2018). Conditions for setting up manufacturers were facilitated by the creation of free zones. ${ }^{42}$ A new law, promulgated in $2015,{ }^{43}$ finally allowed non-pharmacists to inject capital into the pharmaceutical industry (Amari and Pabst, 2016). Two Moroccan pharmaceutical companies and Asian generic manufacturers, including the Indian firm Pharmanova, were approved and began building factories at the end of 2018 . The Tunisian company SAIPH broke ground for its production facility in June $2017,{ }^{44}$ joining the 10 already-established Ivorian companies in 2015 (DPML, 2015).

\section{Failed industrial projects in Benin}

In Benin, none of the technological, financial, or economic conditions encouraged local pharmaceutical production. While drug imports were tax-exempt, imported raw materials were not. Energy, such as electricity, was also very expensive. Local manufacturers were disadvantaged compared to foreign firms that exported medicines in Benin (West and Banda, 2015), which explains why requests to create firms never materialized, other than one from Pharmaquick in 1982. Of the 11 requests submitted to the DPMED between 2001 and $2009,{ }^{45}$ primarily from Beninese, Cameroonian, North African, and Chinese developers, only 5 companies received authorization to establish in Benin, primarily for the production of

\footnotetext{
${ }^{41}$ Because of the crisis, when international firms withdrew capital from Cipharm, their stocks were purchased by the current Director (Ibrahim Diawara), who had still kept some of their licenses.

${ }^{42}$ The Decree of December 6, 2012 created a Public Establishment of an Administrative nature, facilitating the "one-stop shop" approach that could give the pharmaceutical industry advantages: the CEPICI, Center for the Promotion of Investments in Côte d'Ivoire.

${ }^{43}$ Act no. 2015-533 of July 20, 2015 on the practice of pharmacy.

${ }^{44}$ Ivoire Matin, November 26, 2018.

${ }^{45}$ Source: DPMED Pharmaceutical Establishments Unit, August 2016.
} 
solutes, generics, and medical consumables, but none of these projects ever came to fruition. ${ }^{46}$ With no industrial policy supporting local medicine production over imports and because of the way its supply chains operated, Benin became an enclave reserved for medicine imports.

The industrial dynamics described above appear to be linked to the regulatory models adopted by the countries and the resources available to them, as we shall see below.

\section{DIFFERENT REGULATORY MODES: TECHNICAL DIRECTORATE VERSUS AGENCY}

\section{Limits placed on regulation by the Ivorian and Beninese technical directorates}

In the course of the 2000s, technical directorates in Côte d'Ivoire and Benin underwent several institutional reforms to raise their level of expertise. In Côte d'Ivoire, the Gbagbo government reformed operations in the Pharmacy of Public Health (PSP) in $2002^{47}$ and reorganized the DPML in 2006 to make it responsible for applying the government's health policy for pharmaceutical matters. The role of the National Laboratory of Public Health (LNPS) was strengthened through Order no. 198/MSHP of 2009, which made quality control mandatory for all imported medicines. Despite these reforms, these institutions were not satisfactory. In 2008, the National Program for the Development of Pharmaceutical Activity $(\text { PNDAP })^{48}$ was created. Directly attached to the Directorate General of Health Services (DGS), it was charged with implementing the National Pharmaceutical Plan. However, it seemed its mission partially overlapped with the DPLM until its role was better defined. In Benin, functions pertaining to diagnostic explorations were reassigned to the DPM in 2010, which has now become the Directorate of Pharmacy, Medicine, and Diagnostic Investigations (DPMED). ${ }^{49}$ The National Quality Control Laboratory (LNCQ) was created in 2005 with French support from the Chirac and Pierre Fabre Foundations, which provided equipment to improve the quality control of imported medicines.

Although the DPML and the DPMED were made up of sub-directorates that carved up the pharmaceutical sector along different lines, and despite Côte d'Ivoire having better staffed

\footnotetext{
${ }^{46}$ These were the International Pharmaceutical Solutes Company (Société Internationale de Solutés Pharmaceutiques), a Beninese NGO project; the Benin-Pharma BTL SA company for generics production; Biovegemed SA from a technology transfer from the French Pharmaceutical Group Michel Iderne to develop local medicine products based on plant extracts; a Chinese company producing medicines and mineral water, Texmed-Bénin SARL; and another Beninese enterprise to manufacture and package medical consumables.

${ }^{47}$ It gave the PSP the opportunity to manufacture and package some medicines commonly used in hospitals: Act no. 202-334 of June 13, 2002.

${ }^{48}$ It was created by Order no. 308/MSHP/CAB of December 11, 2008.

${ }^{49}$ According to Order no. 4482/MS/DC/SGM/CTJ/DPMED/SA of August 12, 2010 on the attributions, organization, and functioning of the Directorate of Pharmacy, Medicine, and Diagnostic Investigations (DPMED).
} 
human resources than Benin, these technical directorates shared similar dysfunctions. Firstly, in terms of human resources, the DPML in Côte d'Ivoire has about 30 pharmacists, but most of them do not work full-time and/or have not been trained in regulatory matters. ${ }^{50}$ It employs young contract pharmacists who are waiting to open their own pharmacies. The Beninese DPMED suffers from an even greater lack of staff: in December 2016, they numbered six pharmacists (DPMED, 2016): two were civil servants and four were young contractors who were graduates with no specialized training, just as in Côte d'Ivoire. The precariousness of contract employees adds to staff instability and prevents having a body of specialized experts in pharmaceutical regulation.

Moreover, the skills developed by the Beninese $^{51}$ and Ivorian technical directorates in inspection remained quite limited given the industry's small scale. There are still no legally recognized and sworn pharmacist-inspectors in Benin or Côte d'Ivoire, thus rendering their recommendations and decisions ineffective and without legal value. This legal vacuum means that none of the national regulatory authorities of UEMOA member States ${ }^{52}$ conduct inspections abroad. For its part, Côte d'Ivoire does not conduct inspections but rather makes site visits, organized by the companies themselves when requested by the Ivorian directorate. The experts' impartiality might be challenged, knowing that the pharmaceutical companies cover all mission expenses and offer luxury services to the visitors. ${ }^{53}$ More specifically in Benin, the DPMED's lack of resources means employees cannot ensure medicines undergo quality control, conduct inspections abroad, or evaluate Marketing Authorization (MA) applications. For these functions, Benin relies on the expertise of international regulatory authorities and importers based in France and Europe, delegating the bulk of the evaluation and quality control work to them for imported drugs. In the eyes of DPMED regulators, these intermediaries offer sufficiently reliable and robust quality assurance systems. This last point, especially evident in the case of Benin, clearly shows how processes that mutually reinforce local production and pharmaceutical regulation are entangled. Côte d'Ivoire, which has strengthened the capacities of its National Laboratory, performs these controls and evaluations itself. However, since products come from central procurement offices located in

\footnotetext{
${ }^{50}$ The majority of deputy directors are professors at the School of Pharmacy.

${ }^{51}$ Its employees have only conducted one inspection of the Pharmaquick production site, on March 15-17, 2010. To our knowledge, it is the only inspection carried out, for which documents were archived in the Pharmaquick files at the DPMED in Cotonou (Source: observation within the DPMED Pharmaceutical Establishments Unit between 2014 and 2016).

${ }^{52}$ Created in 1994, the West Africa Economic and Monetary Union is composed of eight francophone member States, with the goal of creating a harmonized and integrated economic zone. Source: http://www.uemoa.int/fr/presentation-de-luemoa, accessed March 3, 2019.

${ }^{53}$ Interview in August 2017 with a staff member from the regional pharmaceutical sector.
} 
France, such as Planet pharma, a subsidiary of Ubipharm, the country takes advantage of the guarantees offered by established supply chains.

In closing, the DPMED's organization complicates the effective performance of its duties since it has five units that focus on all regulatory functions. ${ }^{54}$ The Pharmaceutical Legislation, Regulation, and Governance Unit, for example, covers five of the regulatory functions on its own (WHO, 2003; WHO, 2006), ${ }^{55}$ each of which must be assigned to a single unit. The lack of financial resources adds to these shortcomings. Both countries have a backlog of MA applications and follow-up monitoring. ${ }^{56}$ The fees charged for MAs by the two directorates are low, and their lack of resources prevents them from developing sufficiently solid expertise that would justify raising their fees.

In summary, the technical directorates of Benin and Côte d'Ivoire have little functional autonomy compared to the Ministry of Health and suffer from inefficient internal organization and inadequate financial resources and technical staff, hampering their analytical capacities and offering minimal scientific expertise to the State. We will now use the case of Ghana and more recently Côte d'Ivoire, to see whether an agency can serve as a model to address the dysfunctions noted in the technical directorates.

\section{An agency model: the Food and Drug Authority in Ghana}

In October 2012, the Ghanaian parliament approved the Public Health Act, which created the Food and Drugs Authority (FDA), a legal entity separate from the State, responsible for providing and enforcing norms and standards for the sale of medicines (Republic of Ghana, 2012). One year after its creation, the organization that transitioned to the FDA was restructured and five specialized divisions were created, including the drug registration and inspectorate division $^{57}$ (WHO, 2014), which oversees the departments that support local industry and law enforcement. This reform also prompted the hiring of ten additional pharmacist-inspectors, primarily from the industrial sector, who were assigned to the new Drug Enforcement Department. The quality control laboratory is under the direct responsibility of the FDA chief executive officer and is located within the FDA's institutional headquarters in Accra, which has housed the entire staff since 2013 in a brand-new three-

\footnotetext{
${ }^{54}$ A Pharmaceutical Legislation, Regulation, and Governance Unit; a Pharmaceutical Establishments Unit; a Diagnostic Investigations Unit; a National Medical Imaging and Radiation Protection Unit; and a Medicinal Plants Unit.

55 Drug regulation, evaluation, inspection, quality control and monitoring of medicines on the market, and pharmacovigilance.

${ }^{56}$ Sources: Interview with Professor Anglade Malan in Abidjan, 2015; observations conducted at the DPMED in Cotonou.

${ }^{57}$ At the time it was created, it had four departments: drug evaluation and registration, drug enforcement, herbal medicine, and tobacco.
} 
story building. ${ }^{58}$ The FDA has nearly 500 employees, including about 50 pharmacists (FDA, 2014). That same year, the FDA department supporting local industry developed a road map to guide local companies in the process to meet the standards of good manufacturing practices (GMP) by 2020, ensuring the drug's quality at each step of its production. ${ }^{59}$ The road map also provides for the creation of a regional center in Ghana for bioequivalence studies so that Ghanaian companies can conduct these studies locally at a lower cost. These studies are required for WHO prequalification certification, in addition to GMP standards, to guarantee a generic's similarity with the reference medicine (Lantenois and Coriat, 2014). The FDA has a dual goal: to guarantee the quality of medicines distributed on the private market and to support Ghanaian companies in their quest to obtain WHO prequalification, a precondition for access to markets subsidized by transnational actors, such as the Global Fund.

Although it remains under the Ministry of Health, the FDA's new status grants it greater autonomy than that of a conventional public service administration. Nevertheless, its fiscal plans are still subject to approval by the Ministry of Finance and Economic Planning, since it receives an annual operating budget, allocated by the State and approved by the Parliament, defined according to planned activities. Until 2012, approximately $75 \%$ of the operating budget came from the government (WHO, 2014). Drug registration fees are another source of considerable funding. The FDA keeps half of the amounts received and pays the other half to the State. ${ }^{60}$ The Public Health Act authorizes the FDA to hire the staff needed to perform its functions, but like all public health institutions it must obtain a financial authorization for each new hire (FDA, 2012), causing delays. The government would ultimately like the FDA to pay its staff with its own funds, which will give it greater autonomy and independence (Benamouzig and Besançon, 2005).

Hence, the FDA in Ghana has gradually come into being through an endogenous process since the 1990s with occasional financial and technical support from external partners (USAID, WHO, USP), with the primary goal of ensuring the quality of drugs distributed on the domestic market.

\section{Creation of the Ivorian Pharmaceutical Regulatory Agency (AIRP)}

In Côte d'Ivoire, plans to create an agency, driven by Ivorian specialists in the pharmaceutical sector, materialized much faster on the recommendations of the ECOWAS and international

\footnotetext{
${ }^{58}$ The FDA has its headquarters in Accra, nine regional offices, set up between 2003 and 2011 across the country, along with control offices at the country's official entry and exit points for goods (the Port of Tema and Kotoka International Airport).

${ }^{59}$ UNIDO, the United Nations Industrial Development Organization, has supported this initiative on a regional scale since 2015.

${ }^{60}$ In 2013, the cost of registering an imported drug was USD 3600 and USD 270 for locally produced drugs.
} 
experts, ${ }^{61}$ and with technical and financial support from the French Development Agency (AFD). In 2015, the Ivorian government set out to reorganize the existing regulatory institutions to create an agency through the Debt Reduction-Development Contract (C2D) ${ }^{62}$ and the Project to Support the Revitalization of Côte d'Ivoire's Health Sector (PARSSI) funded and managed by the French Development Agency (Allemand, 2017). First, the Pharmacy of Public Health changed its status to become an N-PSPCI, a nonprofit organization, thus granting it the autonomous management that it had lacked. The National Laboratory of Public Health's capacities were bolstered through staff training and the provision of equipment and reference samples. The DPML's legal powers were also strengthened, and the various sub-directorates' responsibilities were redefined. This process prepared for reconfiguring the existing institutions by redefining their functions, organizing them into the three specializations covered by the Ivorian agency (Ouattara, 2018). At the same time, various legal provisions point to the Ivorian system's similarities to the Ghanaian model. For example, the Order of Pharmacists of Côte d'Ivoire was reorganized in 2015 and now categorizes producers, wholesale-distributors, and promotion agencies together.

Launched in 2015, the process to create the Ivorian Pharmaceutical Regulatory Agency culminated in 2017 with a vote on Act no. 2017-541 of August 3 and its implementation decree in February 2019. Responsible for the management of the pharmaceutical sector, it conducts surveillance and enforces penalties for violators, ${ }^{63}$ which entails establishing a body of inspectors made up of sworn pharmacists (Ouattara 2018). According to these promoters, this agency should be able to guarantee industrial investments by cleaning up the market, especially by eliminating informal circuits (Ouattara, 2018). While it is difficult to assess the effects of such recent changes, an analysis of the creation process for the AIRP in Côte d'Ivoire highlights the role played by local medicine production in constructing regulatory systems. The local protagonists supporting the AIRP defended the plan to create the agency as a way to install a regulatory system that is robust enough to meet the development goals of the national pharmaceutical industry.

\footnotetext{
${ }^{61}$ Sources: minutes from the seminar to share results of the experts' work (Professor Amor Toumi, Professor of Pharmacy, Tunisia; and legal experts Mr. Bernard Hody of Belgium and Ms. Victoire Ayeoura of Côte d'Ivoire) and discussions with the various involved regulatory bodies, April 27, 2015 in Abidjan.

${ }^{62}$ The 1st C2D - Debt Reduction-Development Contract — managed by AFD for Côte d'Ivoire, was signed on December 1, 2012 in Abidjan for an amount of 630 million euros, or 413.25 billion CFA francs. The second C2D (2014-2020) was signed on December 3, 2014 in Paris for an amount of 738 billion CFA francs. The C2D enables countries to reconvert French debt through grants to fund development. (C2D.gouv.CI, accessed November 25, 2018.)

${ }^{63}$ Penalties may range from suspension to permanent withdrawal of the authorization to practice, cancellation of the MA, or destruction of products. They may also be financial (up to one billion CFA francs) or criminal (ranging from two months to ten years in prison).
} 


\section{CONCLUSION}

Where medicines are made and how they are procured-direct imports, via a central procurement office and/or local production - affect the instruments deployed by States to guarantee the quality of the products distributed to their populations. Control systems, applied through factory inspections and drug registration, are key factors, requiring learning and investment. In Ghana, the presence of local drug production developed since independence and the importation of generics directly from Asia helped build robust national regulation. The phenomenon of cooperation (Hauray, 2006) between the regulatory authority and the local companies also plays an important role by creating a space for mutual learning between manufacturers and regulators. Comparing this to the situations of Benin and Côte d'Ivoire highlights the importance of strengthening institutional regulatory capacities to attract direct foreign investment and to structure the industrial landscape. More than the legal form of the national regulatory authority, the training and number of pharmacists dedicated to regulatory issues promote the emergence of regulatory systems and industry growth.

In order to eliminate the heterogeneity of regulation between West African States, a regulatory harmonization process was launched at the regional level to homogenize laws and transform technical directorates into autonomous agencies. ${ }^{64}$ Desired by the region's countries themselves, this process is seen as a public health tool whose goal is to promote access to quality medicines. It is accompanied by the creation of a common market aimed at increasing trade in the region. Far from being complete or free of any challenges, this homogenization does help develop and support local drug production, making it instrumental in establishing pharmaceutical sovereignty for countries in the West-African region.

${ }^{64}$ http://www.nepad.org/programme/african-medicines-regulatory-harmonisation-amrh, accessed July1, 2019. 


\section{References}

Allemand C., 2017, «La mise en place des agences du médicament dans la région UEMOA, transfert, hybridation et convergence d'un modèle d'action publique », Mémoire de fin d'études de M2-Politiques de l'alimentation et gestion des risques sanitaires », encadré par Gwenola Le Naour et Sébastien Gardon, Sciences Politiques Lyon, 68 p.

Amari A.S., Pabst J.-Y., 2016, « 2015, les évolutions législatives du secteur pharmaceutique ivoirien: un progrès attendu depuis plus d'un demi-siècle », Revue Générale de Droit médical, $\mathrm{n}^{\circ} 22$, pp. 203-214

Aouely P., Bih N. et Kacou E., 2017, «La production locale de médicaments face aux enjeux d'accessibilité : l'exemple de Pharmivoire Nouvelle », Secteur Privé \& Développement, La revue de Proparco, SP\&D 28, $4^{\mathrm{e}}$ semestre 2017, pp. 30-33.

Arhinful D.K., 2003, « The solidarity of self-interest. Social and cultural feasibility of rural health insurance in Ghana », thèse de doctorat en anthropologie sous la direction de Sjaak van der Geest, African Studies Centre, Leiden, 241 p.

Barral E., 2008, Rhône-Poulenc : des molécules au capital, Paris, Ateliers Fol'Fer, 282 p.

Baxerres C., 2013, Du médicament informel au médicament libéralisé : Une anthropologie du médicament pharmaceutique au Bénin, Paris, Les Editions des Archives Contemporaines, 317 p.

Baxerres C., 2018, «D'intermédiaire informel, devenir détaillant, grossiste puis producteur pharmaceutique: les trajectoires «vertueuses» des hommes d'affaires du médicament au Ghana », dans Baxerres C., Marquis C. (dirs.), Régulations, Marchés, Santé : interroger les enjeux actuels du médicament en Afrique / Regulations, Markets, Health : questioning current stakes of pharmaceuticals in Africa, HAL, Ouidah (Actes de colloque), pp. 30-40.

Benamouzig D. et Besançon J., 2005, «Administrer un monde incertain : les nouvelles bureaucraties techniques : Le cas des agences sanitaires en France », Sociologie du Travail, Elsevier Masson, Vol. 47, n³, pp. 301-322.

Boateng K.P., 2009, « A Study to Determine the Factors Affecting the Compliance of Local Pharmaceutical Manufacturers to International Best Practices in the Pharmaceutical Industry A Case Study of Danadams Pharmaceutical Industry Limited », Thesis submitted to the Paris Graduate School of Management in partial fulfilment for the award of MBA in Strategic \& Project Management, $117 \mathrm{pp}+$ annexes.

Braudel F., La dynamique du capitalisme, Arthaud, 1985, 120 p.

Caubin A., 2010, « La coopération économique chinoise en Afrique de l'Ouest : exemple de la Côte d'Ivoire ", Mémoire de recherche, Sciences Politiques, Université de Toulouse, 100 p. https://docplayer.fr/5270977-La-cooperation-economique-chinoise-en-afrique-de-1-ouest-1exemple-de-la-cote-d-ivoire.html

Chaudhuri S., 2005, The WTO and India's pharmaceutical industry: patent protection, TRIPs and developing countries, New Delhi, Oxford University Press, 358 p. 
Coulegnon T., 2013 (nov.), «UBIPHARM, n 1 de la distribution de médicaments en Afrique francophone », Forbes Afrique, pp. 34-35.

Coulibaly A., 2018, «West Africa Inside the African Market », International business and investment forum, Bonn, Gemany, 13 p. https://www.unido.org/sites/default/files/files/201803/Assane\%20Coulibaly_\%20UNIDO_West\%20Africa_Inside\%20the\%20African\%20Pharm a\%20Market_01032018\%20Bonn.pdf.

DPMED, 2016, Liste du personnel de la Direction de la Pharmacie, du Médicament et des Explorations Diagnostiques, 3 p.

DPML, 2015, Politique Pharmaceutique Nationale 2015, Ministère de la Santé et de la Lutte contre le Sida, République de Côte d'Ivoire, 47 p.

Eberhardt, M., et Teal. F., 2010, «Le Ghana et la Côte d'Ivoire : une inversion des rôles », Revue internationale de politique de développement, $\mathrm{n}^{\mathrm{o}} 1$, pp. 37-54.

FDA-Ghana, 2011, «Annual Report FDB », Accra, Ministry of Health, FDB, 63 p.

FDA-Ghana, 2012, «FDA 2012 Annual Report », Accra, Ministry of Health, FDA, 59 p.

FDA-Ghana, 2013, «FDA 2013 Annual Report », Accra, Ministry of Health, FDA, 63 p.

FDA-Ghana, 2014, «FDA 2014 Annual Report », Accra, Ministry of Health, FDA, 73 p.

FDA-Ghana, 2015, «FDA 2015 Annual Report », Accra, Ministry of Health, FDA, 15 p.

Gaizer S., 2015, «Local Pharmaceutical Industry in Ghana », Chairman industrial Pharmacist Association, Accra, 4 p.

Gbetoenonmon A., 2013, «Le Bénin en Afrique de l'Ouest: visions, défis et contraintes économiques », Cotonou, Friedrich Ebert Stiftung, 37 p. https://library.fes.de/pdffiles/bueros/benin/10691.pdf

Guennif S. et Mfuka C., 2003, «La lutte contre le sida en Thaïlande : de la logique de santé publique à la logique industrielle », Sciences sociales et santé, Vol. 21, n 1, pp. 75-98

Hauray B., 2006, L'Europe du médicament. Politique, expertise, intérêts privés, Paris, Presse Sciences Po., 368 p.

Lantenois C et Coriat B., 2014, «La «préqualification » OMS : origines, déploiement et impacts sur la disponibilité des antirétroviraux dans les pays du Sud », Sciences Sociales et Santé, Vol. 32, pp. 71-99.

LeFur L., 1896, État fédéral et Confédération d'États, Paris, 443 p.

Lewis W.A., 1953, « Report on Industrialisation and the Gold Coast », Accra, Gold Coast Government, $23 \mathrm{p}$.

Mackintosh M., Banda G., Tibandebage P. et Wamae W., 2015, dir. Making Medicines in Africa, Palgrave Macmillan, 334 p.

Mazuet J., 1987, Portrait. Jean Mazuet : souvenirs d'Afrique, Afrique pharmacie, Bulletin de liaison de l'association pharmaceutique interafricaine, $\mathrm{n}^{\circ} 4$, p. 7. 
OMS, 2003, «Une réglementation pharmaceutique efficace : assurer l'innocuité, l'efficacité et la qualité des médicaments ", Perspectives politiques de l'OMS sur les médicaments Genève, OMS, nº 6 p.

OMS, Bureau régional de l'OMS pour l'Afrique, 2006, « Lettre d'information pharmaceutique, La réglementation pharmaceutique dans les pays francophones de la région africaine », Vol. 3, n 1,4 p.

Ouattara M., 2018, « La loi n 2017-541 du 03 aout 2017 : quel apport pour la régulation du secteur pharmaceutique en Côte d'Ivoire », communication présentée au $19^{\mathrm{e}}$ forum pharmaceutique international, Ouagadougou, Burkina Faso.

Republic of Ghana, 2012, «Public Health Act 851 », Accra, Assembly Press, 194 p.

Ruffat M., 1996, 175 ans d'industrie pharmaceutique française. Histoire de Synthélabo, Paris, La Découverte, 270 p.

Senah A. K., 1997, Money Be Man. The popularity of medicines in a rural Ghanaian community, Amsterdam, Het Spinhuis, 256 p.

Simonetti R., Clark N. et Wamae W., 2015, «Pharmaceuticals in Kenya : The Evolution of Technological Capabilities », in Mackintosh M., Banda G., Tibandebage P. et Wamae W. (éds), Making Medicines in Africa, Palgrave Macmillan, 334 p.

Sueur N., 2017, La Pharmacie Centrale de France. Une coopérative Pharmaceutique au XIXe siècle, Presses Universitaires François Rabelais, coll. «Perspectives historiques », Tours, $411 \mathrm{p}$.

Swainson N., 1987, «Indigenous Capitalism in Postcolonial Kenya », in Lubeck P. M., The African Bourgeoisie: Capitalist Development in Nigeria, Kenya and the Ivory Coast, Boulder, CO: Lynne Rienner Publishers, pp. 137-163.

West A. et Banda G., 2015, « Finance and Incentives to Support the Development of National Pharmaceutical Industries», in Mackintosh M., Banda G., Tibandebage P. et Wamae W. (éds.), Making Medicines in Africa, Palgrave Macmillan, 334 p.

Whitfield L., Jones E., 2007, Ghana: the political dimensions of aid dependance, Global Economic Governance Programme, Centre for international studies, university college, Oxford, Oxford University, 27 p.

WHO, 2014, « Report of the preliminary assessment of the National Medicines Regulatory Authority of Ghana », Genève, 69 p.

Archives:

Janvier 1960, Public Records and Archives Administration Department (PRAAD), Ministry of Industry, GH/PRADD/RG.7/1/39, Accra, Ghana. 